\title{
Implementation arrangements for climate adaptation in the Netherlands: characteristics and underlying mechanisms of adaptive governance
}

\author{
Arwin van Burren $^{1}$, Andrea M. Keessen ${ }^{2}$, Corniel van Leeuwen $^{1}$, Jasper Eshuis ${ }^{1}$ and Gerald Jan Ellen ${ }^{3}$
}

\begin{abstract}
Adaptation to climate change is a rapidly emerging policy domain. Over the last decade we have witnessed many attempts to enhance the climate robustness of agriculture, urban development, water systems, and nature to an increase in flood and drought risks due to a higher variability in rainfall patterns and sea level rise. In the vulnerable Dutch delta, regional authorities have developed adaptation measures that deal with flood risk, the availability of fresh water, subsidence, and salt water intrusion. In view of all the uncertainties that surround climate change, scientists emphasize that it should be possible to make changes when conditions change or insights evolve. The concept of adaptive governance has been introduced to facilitate the process of climate adaptation. Adaptive governance requires the availability of governance arrangements that facilitate adaptiveness by being flexible to enable adjustment. Although flexible arrangements for adaptation to climate change make sense from an adaptive governance perspective, from a more bureaucratic, political, and legal perspective, there might be good reasons to make arrangements as solid and robust as possible. In this article we answer the question to what extent the arrangements used to implement various adaptation measures are really adaptive and what mechanisms play a role in obstructing the accomplishment of adaptive arrangements. By analyzing and comparing nine adaptation cases, dealing with different climate issues, and the arrangements used to implement them from both a governance and a legal perspective, we are able to get more detailed insight into the main characteristics of the selected arrangements, their degree of adaptiveness, and the main hampering mechanisms for the creation or functioning of adaptive arrangements.
\end{abstract}

Key Words: adaptive governance; climate adaptation; flexible arrangements; governance; implementation

\section{INTRODUCTION}

Changing climate conditions pose serious challenges to policy makers and politicians (Giddens 2009). They are urged to think not only about ways to mitigate climate change by reducing the emission of $\mathrm{CO}_{2}$, but also to adapt to a rising sea level, more intense rainfall and periods of drought, higher river discharges, and salt water intrusion. Climate change is a complex phenomenon surrounded with deep uncertainty (Füssel 2007). Uncertainty urges decision makers to think about flexible and reversible strategies that can be adjusted to new understandings (Hallegatte 2009). Therefore, dealing with climate change requires an adaptive approach (Adger et al. 2005) in which actors learn to understand the impact of climate change and to optimize how they respond to these impacts. Such an adaptive approach enables actors to maintain or improve the viability of a system under variable or changing conditions (Fankhauser et al. 1999).

The specific characteristics of climate change, its complexity, ambiguity, uncertainty, and versatility (see Van Buuren et al. 2014), have implications for crafting adaptation strategies. The challenge is to accept the dynamics and uncertainty, to be prepared for unexpected feedback patterns (Folke et al. 2005), and to maximize opportunities for learning and experimentation. Climate adaptation therefore asks for an approach based on continuous learning, experimentation, wide participation, and flexibility (Adger et al. 2005, Folke et al. 2005, Huntjens 2011, Termeer et al. 2011).

The concept of adaptive governance, extensively discussed in relation to natural resource management and ecosystem management, is increasingly applied in the context of climate change adaptation (Adger et al. 2007, Brunner and Lynch 2013).
Adaptive governance is designed to deal with uncertainty and change in complex social-ecological systems in an integrated and multidisciplinary manner (Folke et al. 2005, Olsson et al. 2006). It is based on a process of continuously monitoring to gain knowledge about the functioning of actual strategies and to improve these strategies (Pahl-Wostl 2007). This means that it is a step-wise and reflexive process with room for learning and experimentation (Huntjens et al. 2012).

Learning is generally recognized as an important aspect for adaptive governance (Folke et al. 2005, Armitage et al. 2008, Plummer et al. 2013). Learning helps to deal with or reduce uncertainty (Lebel et al. 2010). It provides understanding of the functioning of the system and thereby a basis for adaptive measures (Armitage et al. 2008, Lebel et al. 2010). One way to learn is through experiments because they provide opportunities to gain new insights and reflect on existing approaches (Cundill and Rodela 2012). Experiments are available in different forms: large plot landscape experiments, simulations modeling, and adaptive experimentation and adaptive implementation (see Cook et al. 2004). Experiments are of particular interest for the practice of adaptation; they enable continuous learning, which facilitates a process of step-wise implementation that is flexible and adaptive (Huitema et al. 2009).

Polycentric governance is another essential characteristic of adaptive governance. Within a hierarchical governance system, without enough redundancy, variety, and dispersion of power, it is deemed rather difficult to deal with disturbances and unforeseen circumstances (Chaffin et al. 2014). Overlapping responsibilities can contribute to the resilience of a governance system when parts of it fail (Huitema et al. 2009).

${ }^{1}$ Department of Public Administration, Erasmus University Rotterdam, ${ }^{2}$ Utrecht Centre for Water Oceans and Sustainability Law, Utrecht University, ${ }^{3}$ Urban Water and Subsurface Management, Deltares 
Participation of a wide range of diverse actors in decision making and implementation is a crucial aspect in organizing adaptive capacity to deal with the complex characteristics of climate adaptation (Van Buuren et al. 2014). Participation is not only necessary to create commitment to processes that are inherently unpredictable, but is also important to mobilize different sources of knowledge with which uncertainty can be reduced (Newig et al. 2005, Huitema et al. 2009, Pahl-Wostl 2009). Adaptation strategies cross sectors (water management, nature conservation, agriculture, recreation), scales (local, regional, national), and governmental jurisdictions and therefore imply inclusive approaches and wide participation. In the context of adaptive governance it is also important to emphasize the notion to adjust participation because of changing contextual conditions. It can be necessary to restrict or widen participation in different phases of a project because of changing objectives and circumstances. Possibilities to enter or to leave the arena are thus an important, but often overlooked, element of participation in an adaptive governance perspective.

Introducing adaptive governance, following these principles, presupposes the availability of governance arrangements that facilitate this adaptiveness, by being flexible and enabling adjustment (Gupta et al. 2010). The adaptive governance paradigm has rapidly emerged as a new way of managing in complex social-ecological contexts (Olsson et al. 2006). At the same time this approach can be characterized as mainly conceptual and also highly normative and prescriptive. Many of the best practices advocated in the literature have hardly been put to the test. Indeed, it has so far been more influential "as an idea than as a practical means" (Lee 1999) and its application is hindered by many obstacles (Allen and Gunderson 2011), as is the case when it comes to the implementation of adaptation measures as such (Moser and Ekstrom 2010, Biesbroek 2014).

In this article, we answer the question: To what extent are the arrangements used to implement various adaptation strategies really adaptive (we will use the term flexible hereafter) and which barriers play a role in obstructing the accomplishment of flexible arrangements? Barriers are defined rather differently in the literature on climate adaptation (Biesbroek 2014), but most commonly as conditions that make it difficult to realize something intended. Authors distinguish between subjective or objective constraints (Sutton and Tobin 2011). Following Biesbroek (2014), we argue that it is important to unravel the mechanism behind a barrier, i.e., the operative mechanism that explains why an impasse occurs. Following this, a barrier can thus be seen as a hampering mechanism. By analyzing and comparing nine Dutch adaptation strategies, dealing with different climate issues, and the arrangements used to implement them from an interaction and a legal perspective, we provide more detailed insight into the main characteristics of flexible arrangements, their degree of adaptiveness, and the main hampering mechanisms that prevent the creation of flexible arrangements and result in the use of solidified arrangements.

The article is structured as follows. First, we outline in section 3 the relation between adaptive governance and flexible implementation arrangements for adaptation measures. In this section we also critically reflect on the issue of flexible arrangements. In section four we describe our research methodology. Section five contains our empirical description and an overview of the main characteristics of flexible arrangements as found in our cases. Then we describe in section six the main mechanisms that prevent flexible arrangements in the cases we analyzed. In section seven we conclude our paper and critically reflect on both our theoretical starting-points as well as the empirical practice of climate adaptation.

\section{FLEXIBLE ARRANGEMENTS}

Flexible arrangements are considered important for facilitating step-wise implementation trajectories with room for experimentation and participation (Van Tatenhove 2013). As such they are an indissoluble ingredient of adaptive governance and dynamic, learning implementation processes (Craig 2010). Flexible arrangements are considered key prerequisites for the adaptive implementation of climate change adaptation measures. After all, adjusting policy strategies due to changing insights or circumstances and continuous learning is only possible when actors can also easily adjust the ways of collaboration, the mutual agreements, and the rules of collaboration. Flexible arrangements are meant to enable ongoing interaction between public authorities, private contractors, and societal stakeholders in changing circumstances. They keep options open and facilitate learning and adjustment of goals and strategies when changing circumstances are a reason to do so. As such, flexible arrangements are the opposite of solid, fixated arrangements that are difficult to adjust. When actors will adjust a certain measure they thus have to change these rules and agreements to enable these adjustments.

Flexible arrangements have different appearances and can be either contractual or organizational, formal or informal, facilitating the interaction between actors and the distribution of resources. In our conceptualization of arrangements we distinguish between the rules and conventions that structure the process of interaction or collaboration, and the legal conditions of a specific arrangement, which constitutes the result of this process and determines its future.

\section{Flexible arrangements from an interaction perspective}

With regard to interaction, arrangements can be seen as a specific set of "rules of the game": formal and informal rules that structure interactions between several actors active around the implementation of adaptation strategies (e.g., March and Olsen 1989, Klijn 1996, Scharpf 1997).

\section{Characteristics}

With regard to the interactional component, flexible arrangements can be recognized by the following characteristics:

1. Flexible processes: processes of decision making allow for speeding up and slowing down and for entry and exit of actors during the process;

2. Flexible content: there are possibilities to change scope, time horizon, and goal of adaptation strategy;

3. Flexible organizational structure: there are possibilities to change the organizational form when the collaboration necessitates it. 
First, flexible arrangements can be recognized by the flexibility of (interaction) processes. In flexible arrangements the decisionmaking process can be speeded up and slowed down. This means that deadlines and time horizons can be changed. Furthermore, flexible arrangements allow for fluid actor compositions over time (Berkes and Jolly 2002). The arrangement is open and inclusive to participation from different stakeholders over time. When agendas evolve over time, the arrangement is capable of and open to the introduction other actors in the arrangement with the aim of learning and changing the focus of the climate adaptation strategy.

Second, flexible arrangements can be recognized by their flexible content. In a flexible arrangement there are possibilities to change scope, time horizon, and goals of the adaptation strategy. For example when the monitoring of the climate change of adaptation strategy proves that the negative consequences of, for example, higher river water discharges are felt in other areas than assumed, the arrangement is capable of changing its scope. Furthermore, in a flexible arrangement, the time horizon of the adaptation strategy can be changed (Zerubavel 2003, Pierson 2004). When, for example, droughts are felt heavier than expected, measures can be realized earlier than originally scheduled.

Third, flexible arrangements are characterized by flexible organizational structures. With structures we refer to the formal and informal rules that are used to arrange the collaboration process between actors. In other words, flexible arrangements offer the possibility to change the organizational structure of collaboration. In flexible arrangements, structural provisions are only limitedly fixed. There is a strong focus on trust between actors. For example, when the impact of climate change develops differently than expected, actors are able to change their form and rules of collaboration (procedures, institutional cooperation arrangement) with the aim of adapting to climate change.

\section{Barriers}

The development and implementation of flexible arrangements in climate adaptation strategies is not always a smooth or easy process. From the literature on adaptive governance, there are several potential factors that prevent flexible arrangements to be realized:

\section{Conflicting time frames and interests;}

2. Obscure distribution of responsibilities between actors;

3. Unclear distribution of costs and future benefits;

4. Lack of trust between participants (see e.g., Amundsun et al. 2010, Biesbroek et al. 2011).

At first, conflicting time frames can hamper the implementation of flexible arrangements (Cosens 2010). In the literature (Biesbroek et al. 2010), the short time horizon of politicians and the more long-term orientation of climate change are mentioned as an important example. Short-term orientation can lead to tight schedules, temporary budgets, and a drive to rigid contracts. The character of climate change on the other hand calls for a rather long-term orientation and flexible arrangements. A related barrier for the implementation of flexible arrangements is the existence of conflicting interests. Nowadays many stakeholders are involved in the implementation of climate adaptation strategies (Pahl-Wostl 2009). These stakeholders, for example, farmers, fishery, and governmental agencies, have different and often conflicting interests. Thus, implementing climate adaptation strategies is often controversial. Actors therefore aim for formal agreements in which their interests are fully covered.

A second barrier for the implementation of flexible arrangements is the existence of obscure responsibilities between several actors. Climate adaptation strategies involve the effort of many actors. For example, the establishment of a flood storage area is a matter for different authorities. Their responsibilities are not always very clear (Naess et al. 2005). This complicates decision making around new flexible arrangements, and may prevent the realization of such arrangements. If an agreement is reached, ambiguity about responsibilities form a driver to make strict contracts without room for flexibility.

The same reasoning applies to the third barrier. Because of the uncertain character of climate change and the impact of different measures, it is sometimes unclear what the costs and future benefits are. For this reason, responsible actors want to hedge themselves against high future costs. In other cases the uncertainties are considered so high that arrangements are not created at all.

The last barrier for implementing flexible arrangements is the lack of trust between actors. Because of the risk of opportunistic behavior, actors want to tie themselves and others to strict arrangements (for example, Gambetta 1988, Ring and Van de Ven 1994). This reduces the flexibility of the arrangements.

\section{Flexible arrangements from a legal perspective}

With regard to the legal characteristics of an arrangement, the focus is on the formal characteristics of implementation arrangements and their flexibility: the binding agreements between actors and the formal prescriptions derived from public law and policy documents. This flexibility can be assessed by analyzing the legal documents that constitute the formal backbone of each arrangement.

\section{Characteristics}

From a legal perspective, flexibility is related to the possibilities, within rules, procedures, and laws, to change scope, time horizon, and goal of an adaptation strategy (flexibility of content). Flexibility is encouraged when the law prescribes a procedural approach. This means that legal rules impose procedural constraints on administrative decision making as they prescribe how these decisions should be made, which factors should be taken into account, and how the impacts should be monitored, without determining the final outcome of the process (Howarth 2009). This approach is increasingly used in European environmental law, including European water law (Gunningham 2009, Howarth 2009) and reflected in Dutch environmental and water law (Van Rijswick and Havekes 2012). This shift away from regulatory, command and control instruments toward more flexible, programmatic approaches is a reaction to the complexity of environmental problems, the desire to use economic instruments, and to cooperate with nongovernmental actors through voluntary arrangements (Gunningham 2009).

The flexibility of arrangements is assessed by analyzing the possibilities to change the agreements between policy makers, 
stakeholders, and recipients, or the applicable public law rules. These possibilities are strongly related to the choice of policy instruments. Some instruments are inherently more flexible than others, like a plan compared to a decision, or an intention agreement to a contract. This is because some instruments are binding and others are not (Mees et al. 2014). Flexibility in the sense of room for manoeuver depends as well on the wording used because their openness or precision can render an instrument more or less flexible in the way they describe the measure, the implementation trajectory for the proposed measure, or what the parties involved have agreed on (cf. Ruhl 2011). In particular, provisions that enable feedback loops are essential to enable flexibility. A feedback loop consists of (1) monitoring, (2) assessment of monitoring data, (3) scientific and social learning from the lessons that the monitoring data offer, and (4) adaptation of the arrangement (Arnold and Gunderson 2013, Craig and Ruhl 2014).

\section{Barriers}

There are several legal aspects that reduce the flexibility of arrangements. They mainly have to do with principles related to the rule of law and good governance, which set clear restrictions on how legal rules can be used. We distinguish between three potential barriers:

1. The perceived need for legal certainty;

2. The need to protect individual rights, e.g., equality principle, the right to property;

3. Procedural guarantees and rights, including the right to judicial protection.

Adaptiveness is not necessarily a key goal of the law (Arnold and Gunderson 2013). Even though it is possible to make the law more flexible to enable change and adaptation, many legal mechanisms remain that make law resistant to change or slow to change (Ruhl 2011). To name but a few, administrative procedures are lengthy because of procedural safeguards, and rules, plans, or decisions may not have expiry dates and property rights must be respected. The law has these features because it aims to provide stability, by offering legal certainty and respecting individual rights and freedoms. However, law also contains elements that enable change, such as open norms and process rules, which offer discretion in the implementation stage (Ruhl 2011). However, it is a real risk that a very flexible law gives too much discretion to the administration, resulting in arbitrariness and abuse of power (Wade and Forsyth 2000). Another serious concern is that a very flexible governance style of decision making results in provisions that cannot be enforced (Green et al. 2013).

This legitimate aim of providing stability conflicts with the dynamics required to adapt to climate change. The inherently maladaptive nature of law can allow, facilitate, or even mandate pathological choices and behaviors with respect to ecosystems (Arnold and Gunderson 2013). Adapting the legal system therefore requires finding a balance between providing enough and the right kind of stability that helps society and ecosystems to absorb shocks and changes without going into decline or collapse, while also providing enough and the right kind of flexibility that helps society and ecosystems to adapt to shocks and changes in resilient and sustainable ways (Garmestani et al. 2008, Benson and Garmestani 2011). Some constraints are necessary for effective decision making and trust in the government (Ebbesson 2010). For instance, the rules on judicial review lead to longer procedures but cannot be set aside in a state under the rule of law. Also, when rules are not enforceable and no one is responsible for compliance or the achievement of concrete and measurable results, the law has become too flexible to serve its purpose (Green et al. 2013).

In table 1 we summarize the above presented characteristics and barriers of flexible arrangements. The barriers we distilled will be used as sensitizing concepts (Blumer 1969) because it is our aim to inductively find out which underlying hampering mechanisms are most important for (not) realizing flexible arrangements.

Table 1. Summary of characteristics of flexible arrangements.

\begin{tabular}{l}
\hline Characteristics \\
\hline Interaction perspective \\
Flexibility of process: possibilities to adjust speed of and \\
actor composition in process \\
Flexibility of content: possibilities to adjust the agenda \\
(scope, time horizon, goal) for collaboration \\
Flexibility of structure: possibilities to adjust the structure of \\
collaboration \\
Fexal perspective \\
and leave room for discretion and manoeuver \\
Flexibility to adjust arrangements: possibilities to change the \\
type of (formal) agreements
\end{tabular}

\section{METHODS}

\section{Research strategy}

We selected the cases by strategic sampling (Flyvbjerg 2006); nine cases were deliberately selected for their rich content regarding flexibility of arrangements for climate adaptation. We knew that the cases were informative regarding the arrangements, because we had researched all cases except one in earlier projects. The caseselection aimed to cover the variety of climate adaptation strategies in the Netherlands to understand the diversity in flexibility of arrangements and the different underlying mechanisms. The cases were spread over the main Dutch climate adaptation themes: fresh water supply (3), water safety (3), water nuisance (2), salinization and drought (1).

The research strategy serves the exploratory aims of this paper; it covers the variety of climate adaptation themes and strategies in the Netherlands, and illuminates the various mechanisms that determine adaptivity of institutional arrangements. An important limitation of this strategy is that the cases represent the variety of adaptation strategies but they are not necessarily representative in terms of the frequency distribution of adaptation strategies. Also, caution should be taken when generalizing the findings of this study outside the Netherlands.

\section{Research methods}

Data were collected through a combination of interviews and document analyses. Formal documents like plans, policy documents, contracts, covenants, and other written agreements were studied to unravel the arrangements in terms of the (flexibility of) rules used. The interview data were gathered 
through 83 semistructured interviews in total (see Table 2). We applied a combination of reanalyses of 51 semistructured interviews conducted in earlier research, and 32 strategically targeted additional interviews to gather specific information that was still lacking. The 32 new interviews were structured following the central concepts of our conceptual model. Regarding the reuse of 51 other interviews, we met several challenges common in secondary analysis. An important challenge with secondary analysis is the congruence between the data and the new research question (Szabo and Strang 1997, Hammersly 2010). We experienced a large degree of congruence because institutional aspects of climate adaptation were an important part of the earlier research. Also, we conducted 31 interviews to gather new data where the secondary data showed gaps. Another challenge with secondary analysis is the often lack of contextual (unrecorded) knowledge that may be important to interpret data correctly (Hammersly 2010, Seal 2011). This was not problematic in this study, because the researchers who gathered the original data were involved, except for one case. For that case we spoke with the original researcher to check our interpretations.

Table 2. List of sources used.

\begin{tabular}{lclc}
\hline \hline Case & $\begin{array}{c}\text { Interviews } \\
\text { from } \\
\text { earlier } \\
\text { research }\end{array}$ & Written analyses used & $\begin{array}{c}\text { Additio- } \\
\text { nal } \\
\text { interviews }\end{array}$ \\
\hline $\begin{array}{l}\text { Noordwaard } \\
\text { Overdiep }\end{array}$ & 9 & Van Buuren et al. 2012 & 3 \\
Midden-Delfland & 0 & Winnubst 2011 & 5 \\
Essche Stroom & 6 & $\begin{array}{l}\text { Eshuis and Van Buuren } \\
\text { 2014 }\end{array}$ & 3 \\
Loosdrecht & 4 & $\begin{array}{l}\text { Breman et al. 2008. } \\
\text { Breman et al. 2011, Ellen }\end{array}$ & 2 \\
Water Farming & 17 & $\begin{array}{l}\text { Vnd Ottow 2012 } \\
\text { Water storage at the 2012 }\end{array}$ & 6 \\
source & 0 & Van Bakel et al. 2013 & 5 \\
Waalblok & 12 & $\begin{array}{l}\text { Van Buuren et al. 2012, } \\
\text { Eshuis and Van Buuren } \\
\text { 2014 }\end{array}$ & 1 \\
Noordwijk & 3 & Gilissen et al. 2010 & 2 \\
\hline
\end{tabular}

The cases were studied by duos of researchers to enhance the validity of our reconstruction. One principal investigator coordinated and checked the research to ensure that the cases were analyzed in the same manner. Of course the analysis was also systemized by using the same theoretical framework with the characteristics and barriers (see Table 1) to analyze all data.

\section{COMPARATIVE CASE PRESENTATION}

These nine selected and qualitatively studied cases are shortly described in Table 3. All cases are aimed at realizing adaptation measures to anticipate long-term climate change consequences, in collaboration among public, private, and societal actors in a context of competing (spatial) ambitions and with a strong desire to pool resources to enable implementation.

It is striking that so many measures are intended to be robust, instead of adaptive ${ }^{[1]}$. The measure is often a single intervention, which has to be a sufficient solution for the next 50 years, for example, the coastal enforcement trajectory of Noordwijk.
Adapting through small incremental steps, and a continuous revision of the adaptation measures, is usually not foreseen in the short term (except in the case of "Water farming"). Even when monitoring takes place, it is merely to stay informed about the environmental impact of measures.

Next to these implementation characteristics, the studied cases show a variety of implementation arrangements. In most of the cases the implementation is marked by a combination of public and private instruments. The state often starts the decisionmaking process by proposing a plan. Only subsequently, participation may influence the choice of measures to implement the initial idea. The level of participation varies. The "Water farming" case constitutes a notable exception because here private initiative took place first. Although in Essche Stroom the authorities encouraged broad participation from the beginning of the implementation process, the inhabitants of the Overdiep polder had to fight for their participation rights to have their proposal become the overall preferred proposal. Next to public law instruments, private law instruments, in particular, agreements, are used.

Formal, written agreements deal with the various aspects of the project and safeguard the public ambitions while enabling some forms of private and shared use. The arrangements used (agreements) allow for customization and for tailor-made agreements between various public and private actors. These agreements are particularly important where the government needs the participation of inhabitants of the area. Some cover compensation for damage caused by governmental action, others determine the cooperation between the citizens and the government in situations where the citizens are directly involved in the implementation of the adaptation measure. For instance, they cover the height of crops in the former polders Overdiep and Noordwaard, and the way farmers should store rainwater in "Storing water at the source" and Waalblok. In Table 4 we show these different implementation arrangements.

\section{RESULTS}

\section{Flexibility of arrangements from an interaction perspective}

In the Tables 5, 6, and 7 we summarize the flexibility of the arrangements used, from an interaction perspective, involving flexibility of process, content, and structure. Nearly all cases are characterized by a funnel-shaped decision-making process in which both the participation of stakeholders and the room to adjust the content of decision making was gradually reduced. In nearly all cases actors tried to combine public and private ambitions. At the same time, especially in the flood management cases, the public ambition to realize the measure just in time and within budget to meet the norm, is decisive for the planning and the organization of the participation process. In the cases focused on water retention and water conservation the public and private ambitions are more equal and thus the processes are more flexible to enable inclusion of private interests and to take into account stakeholder preferences. At the same time the structure of most of the governance process was rather flexible. There were not many formal rules guiding the interaction between participants. The decision-making process was usually mainly structured by unwritten rules, and ad hoc decisions on how to organize the interaction. 
Table 3. Cases: climate adaptation measures.

\begin{tabular}{|c|c|}
\hline Case & Adaptation measure \\
\hline Noordwaard & $\begin{array}{l}\text { Decommissioning the polder Noordwaard as a flood risk management measure within a larger river management project } \\
\text { (space for the river) while keeping the agricultural function intact, and adding new spatial functions such as recreation and } \\
\text { nature. }\end{array}$ \\
\hline Overdiep & $\begin{array}{l}\text { Changing the course and height of a levee, and placing } 8 \text { of } 17 \text { farms on a terp, thus creating a high water retention area } \\
\text { that can be used in case of periodically occurring high water levels. The project was part of a larger river management } \\
\text { project (space for the river). The climate adaptation measures were designed to accommodate current spatial functions } \\
\text { (agriculture, nature, recreation). The measure was suggested by the farmers in the area to prevent worse demolition of all } \\
\text { farms in the area. }\end{array}$ \\
\hline Midden-Delfland & $\begin{array}{l}\text { This case focused on exploring new forms of cooperation between government and farmers to create additional rain water } \\
\text { storage. The farmers (collectively) offered an integrated range of water management and ecosystem services in an area } \\
\text { contract. }\end{array}$ \\
\hline Essche Stroom & $\begin{array}{l}\text { Restoration of the meandering of small streams thus facilitating water retention, nature development, and preservation. The } \\
\text { projects were executed as a long-term program to restore the small rivers' following a stepwise implementation logic. }\end{array}$ \\
\hline Loosdrecht & $\begin{array}{l}\text { Flexible water levels in the recreation and nature area of Lake Loosdrecht. The main goals were to improve the water } \\
\text { quality and have a fresh water buffer in times of drought. The incentive for the water board to initiate this measure was to } \\
\text { achieve ecological goals and reduce costs on water management measures. }\end{array}$ \\
\hline Water farming & $\begin{array}{l}\text { A number of measures aimed to keep the fresh (ground)water in the area to be used for agricultural production processes. } \\
\text { Measures consisted of subsurface water storage and creating water works to keep the water in the small canals next to the } \\
\text { agricultural areas. }\end{array}$ \\
\hline $\begin{array}{l}\text { Storing water } \\
\text { at the source }\end{array}$ & $\begin{array}{l}\text { Measures preventing high levels of discharge water due to heavy rainfall, thus preventing flooding of low lying urban } \\
\text { areas. Two measures were tested/implemented: small levees around the agricultural areas (creating short-term water } \\
\text { basins), and small dams in the waterways temporising the water discharge. }\end{array}$ \\
\hline Waalblok & $\begin{array}{l}\text { Building a "water cleaning factory" and water storage in a glasshouse area. Measure aimed at two goals: preventing water } \\
\text { nuisance due to heavy rainfall and cleaning facility for watering plants in greenhouses. Currently the rain water storage } \\
\text { basins have been built, while the water cleaning facilities are awaiting approval by key stakeholders. }\end{array}$ \\
\hline Noordwijk & $\begin{array}{l}\text { This coastal reinforcement project was part of a national program (weak links) to improve water safety behind the Dutch } \\
\text { coastline. Measure was implemented because of current safety risks and expectations of future sea level rise. The solution } \\
\text { was found in building a dyke into a dune to reinforce the coastline for the next } 50 \text { years. Measure was special because of } \\
\text { the spatial integration. }\end{array}$ \\
\hline
\end{tabular}

Table 4. Main characteristics of arrangements used.

\begin{tabular}{|c|c|}
\hline Case & Main characteristics of implementation arrangement \\
\hline Noordwaard & $\begin{array}{l}\text { Plan space for the river, implemented through administrative decisions, cooperation agreement, covenant (gentlemen's } \\
\text { agreement) concerning maintenance and repair, user agreements (agriculture, recreation, nature). }\end{array}$ \\
\hline Overdiep & $\begin{array}{l}\text { Plan space for the river, implemented through administrative decisions, cooperation agreement between the farmers } \\
\text { (inhabitants) and the involved government organization. }\end{array}$ \\
\hline Midden-Delfland & Bid from the stakeholders in the area to implement the various ecosystem services. \\
\hline Essche Stroom & $\begin{array}{l}\text { Water management plan, user agreement regarding private nature conservation, cooperation agreement between public and } \\
\text { private organizations regarding larger developments concerning (country) estates. }\end{array}$ \\
\hline Loosdrecht & $\begin{array}{l}\text { Bylaw by the water board (approved by the province) providing for a band width and hence a flexible water level, informal } \\
\text { agreements concerning participatory monitoring. }\end{array}$ \\
\hline Water farming & $\begin{array}{l}\text { Green deal: an initiative by the national government to catalyze projects by taking care of issues concerning law and regulation } \\
\text { and providing access to relevant networks. Furthermore the cooperation of farmers has led to a workgroup that cooperates with } \\
\text { the water board. }\end{array}$ \\
\hline $\begin{array}{l}\text { Storing water } \\
\text { at the source }\end{array}$ & $\begin{array}{l}\text { Because this was a pilot, the participants were compensated for their efforts based on a detailed formal agreement/contract. } \\
\text { Future arrangements need further research }\end{array}$ \\
\hline Waalblok & $\begin{array}{l}\text { A regional agreement between regional politicians (2005), and an area agreement between the private parties involved (farmers) } \\
\text { and the government organizations (municipalities and water board). Also a subsidy was provided to facilitate the process. }\end{array}$ \\
\hline Noordwijk & $\begin{array}{l}\text { Weak links program plan, implementation through public decisions, finance agreement, indemnity agreement and maintenance } \\
\text { agreement. A project group was formed to arrange the implementation of the measure. }\end{array}$ \\
\hline
\end{tabular}


Table 5. Flexibility of the process

\begin{tabular}{|c|c|}
\hline Noordwaard & Over time the process becomes less flexible for adjustments and a strict project-management oriented focus on timely realization dominates. \\
\hline Overdiep & $\begin{array}{l}\text { For a long time a flexible process-oriented focus dominated, but after formal decision making a more inflexible project-management } \\
\text { orientation replaced this. }\end{array}$ \\
\hline Midden Delfland & The process was far from flexible because of the many restrictions set by the regional water authority. \\
\hline Essche Stroom & $\begin{array}{l}\text { The process was highly flexible during the decision making and the implementation stage because of the use of a pragmatic and } \\
\text { programmatic approach. }\end{array}$ \\
\hline Loosdrecht & $\begin{array}{l}\text { The process concerning participatory monitoring was flexible. It was less so regarding the decision for the flexible water levels that followed } \\
\text { strict planning procedures. } \\
\text { However, the water authority did show some flexibility in implementing the water levels in phases, after negotiation with stakeholders. }\end{array}$ \\
\hline Water farming & $\begin{array}{l}\text { Very flexible process. It was quite easy to adjust the speed of the implementation process. There were no deadlines in the process. Process } \\
\text { had a strong "learn by doing" focus; actors were allowed to enter and exit the arrangement. }\end{array}$ \\
\hline $\begin{array}{l}\text { Storing water } \\
\text { at the source }\end{array}$ & $\begin{array}{l}\text { Inflexible process in the sense that this was a pilot project with a predefined time schedule, budget, and scope. A fixed set of research } \\
\text { questions lead the process. }\end{array}$ \\
\hline Waalblok & $\begin{array}{l}\text { The speed of developing the institutional arrangement was adjusted continuously. Sometimes speed was reduced because the water board and } \\
\text { other parties needed more time for knowledge development; sometimes it was increased because horticulturalists threatened to leave the } \\
\text { process if speed remained low. }\end{array}$ \\
\hline Noordwijk & $\begin{array}{l}\text { Little room for acceleration and delay. The process had a tight schedule and deadline, Little/no room for exit/entrance of actors during } \\
\text { process. }\end{array}$ \\
\hline
\end{tabular}

$\longrightarrow$

\section{Table 6. Flexibility of the content.}

\begin{tabular}{|c|c|}
\hline Noordwaard & The actual spatial design and functions of the area were adjustable. \\
\hline Overdiep & Inhabitants could develop their own proposal and the proposal of the initiator could be adjusted by adding new elements or changing. \\
\hline Midden Delfland & $\begin{array}{l}\text { Little room for stakeholders to develop their own ideas for the contract because of the many legal conditions formulated by the regional } \\
\text { water authority. }\end{array}$ \\
\hline Essche Stroom & Inhabitants could influence measures because of the subsequent timing of the participation processes along the Essche Stroom. \\
\hline Loosdrecht & $\begin{array}{l}\text { Few possibilities to change scope, time horizon, and goal of adaption. The measure was implemented and monitoring was used to measure } \\
\text { the effects. Because the measure required little intervention in the system, it would be possible to reverse/alter it. }\end{array}$ \\
\hline Water farming & $\begin{array}{l}\text { Many possibilities to change scope and time horizon. Goal of adaptation strategy is fixed (self-sufficiency), but the ways of adaptation are } \\
\text { not fixed. }\end{array}$ \\
\hline $\begin{array}{l}\text { Storing water } \\
\text { at the source }\end{array}$ & $\begin{array}{l}\text { As a pilot, the outcome was the basis for either terminating or continuing the adaptation measure. The pilot resulted in continuation and } \\
\text { further implementation of the adaptation measure. How this will be done is under consideration. }\end{array}$ \\
\hline Waalblok & $\begin{array}{l}\text { The scope of the arrangement was changed from a complete water cleaning and storage facility, to a waterstorage facility. The time horizon } \\
\text { of the water cleaning facility was extended. The short-term goal was reduced to only water storage, but the long-term goal remained to also } \\
\text { clean the water. }\end{array}$ \\
\hline Noordwijk & Few possibilities to change scope, time horizon, and goal of adaption. Fixed measure, but dike in dune can be heightened in the future. \\
\hline
\end{tabular}

Table 7. Flexibility of the structure.

\begin{tabular}{|c|c|}
\hline Noordwaard & $\begin{array}{l}\text { The structure for stakeholder participation was rather well structured and fixated. The same holds true for the project arrangement and the } \\
\text { involvement of formal stakeholders representing collective interests. }\end{array}$ \\
\hline Overdiep & $\begin{array}{l}\text { A flexible structure for stakeholder participation was used that gave room for bottom-up self-organization, because inhabitants had lobbied } \\
\text { hard to participate early in the process. This structure was formalized when the project came to mature. }\end{array}$ \\
\hline Midden Delfland & $\begin{array}{l}\text { Moderately flexible structure: the arrangement used was fixed, but the private stakeholders were able to choose their own structural } \\
\text { arrangement for the green-blue services. }\end{array}$ \\
\hline Essche Stroom & A very flexible structure in time and space with much room for ad hoc networks dealing with specific subprojects. \\
\hline Loosdrecht & $\begin{array}{l}\text { Inflexible and fixated decision-making process, with participation only during the formal participation procedure. This stands in sharp } \\
\text { contrast with the unrelated and very flexible structure concerning participative monitoring. }\end{array}$ \\
\hline Water farming & $\begin{array}{l}\text { Very flexible structure. Actors have temporarily created a study group that is not formally embedded. Structure and participants can be } \\
\text { changed and structural provisions are only partly fixed. Strong focus on trust. }\end{array}$ \\
\hline $\begin{array}{l}\text { Storing water } \\
\text { at the source }\end{array}$ & $\begin{array}{l}\text { Not a flexible structure, the participants were selected and measures were implemented. A group of participants and a project team were } \\
\text { organized as structures to facilitate the process of the pilot. After the pilot this structure dissolved. }\end{array}$ \\
\hline Waalblok & $\begin{array}{l}\text { The development of the arrangement (area contract) was done in a rather loosely organized process. Once the area-contract between the } \\
\text { public authority and one private party was signed and fixed it remained constant. }\end{array}$ \\
\hline Noordwijk & Not a flexible structure. Project group with legal responsibilities, the structural provisions are fixed and based on a 50 years horizon. \\
\hline
\end{tabular}




\section{Flexibility of arrangements from a legal perspective}

In Tables 8 and 9 we present the characteristics of the chosen arrangements in terms of their legal flexibility: the way in which the content is recorded and the suppleness of the arrangements used. All cases feature a mix of policy instruments. The state uses communication, participation, subsidy, and compensation for damage. Traditional instruments dominate the arrangements. Subsidies and compensation for damages are frequently used. That can be explained by considering how much effort it takes to realize an innovative measure and the need to compensate citizens for their cooperation in the delivery of a service to the government. Sometimes innovative policy instruments are used. For instance, in Midden Delfland a tender procedure was used to choose who would build the water storage for what price. In the case "Storing water at the source," a discussion took place about using an auction.

The arrangement usually consists of a combination of flexible and less flexible instruments. The state usually announces and confirms adaptation measures in plans. Plans are flexible instruments that are not binding, easy to change, and against which judicial review is not available. However, if the government is involved in the implementation of an adaptation measures, it may have to take binding decisions, which occurred, for example, in Noordwijk and Lake Loosdrecht.

Both in Noordwijk and in Loosdrecht, interested parties brought proceedings against the main adaptation decision of the government. An interesting difference between these two and other cases is that in these two cases the government implemented the decision without needing any help from citizens (although citizens participate in monitoring in the case of Lake Loosdrecht). In these two cases, the government could impose an adaptation measure, which they did. Also in the case of Noordwaard inhabitants brought proceedings against the decision to create more space by the river by giving up a polder, but they were not able to retain implementation, although they were successful in changing certain elements. In the comparable case Overdiepse Polder, inhabitants considered bringing proceedings to slow the process, but they chose to accept this decision and make their own plan for multifunctional use of the area.

\section{DISCUSSION}

Table 10 summarizes the empirical findings with regard to the five elements we used to assess the flexibility of arrangements. From this table we can derive a couple of interesting observations. First, the overall flexibility of the chosen characteristics is rather disappointing. There is only one case that scores on all elements positively (pilot project "Water farming"). This flexibility can be explained by the pilot status of the project in which all actors involved are willing to give an innovative idea a try and to learn from the pilot. Furthermore, it is the initiative of the involved farmers and the involved water authority has no clear objective but opts for a facilitating and informal role. There is more flexibility regarding the structure of the collaboration during preparing decisions. There is some flexibility with regard to the content of the decision-making process: stakeholders are allowed to add new elements or to propose alternative adaptation measures. However, in many cases the process of decision making is not very flexible but prestructured by way of procedural guidelines and formal steps. This applies in particular to the flood management projects, which have a strong focus on timely realization of the predefined safety norms.

It is interesting to note that the cases are at first quite flexible from an interaction perspective. Involved public officials use the room they perceive to have to operate within the legal framework. This is visible with regard to the content of arrangements. The content in terms of scope is rather dynamic and open for change. However, when parties have agreed on the content, this radically changes.

From a legal perspective the flexibility of the arrangements is therefore rather low. The content of decision making is strongly fixed in formal and binding decisions and agreements. Much is invested in consolidating the outcomes of processes of collaboration and negotiation and there are few, if any, provisions for adjusting these outcomes over time. The same holds true for the type of agreements that is chosen. Although measures are announced in plans, they are established by binding instruments, in particular public decisions without expiry dates and contracts, which can only be changed when all involved actors agree to do so. In general, the intention is to fix appointments, not to enable changing them.

In most cases the collaboration is focused on the realization of projects, not on the phases of exploitation and maintenance after implementation. That also means that actors try to finalize their collaboration when they have realized an agreement that enables implementation. Choosing robust measures and rigid legal instruments instead of flexible ones, fits into this strategy. When a robust measure is realized, it is not necessary to continue interaction over the question of whether adjustments are necessary. Although we did not empirically test this, it seems plausible that actors prefer such a pragmatic approach to minimize administrative transaction costs.

It is also possible to adopt a different type of adaptation measure, like in Waalblok and "Storing water at the source." In these cases the chosen measures can be changed depending on the circumstances. Such measures require constant monitoring and ongoing dialogue. More adaptive measures thus ask for ongoing participation. Note that involving locals to a great extent, as happened in Essche Stroom, Overdiepse polder, and Noordwaard, is related to greater adaptivity of the choice and implementation of an adaptation measure during the decisionmaking stage.

\section{CONCLUSIONS}

Reflecting upon our cases we can conclude that there are at least four hampering mechanisms that explain why most of the implementation arrangements used are not very flexible. First, there is a strong focus on goal realization and safeguarding this result for the future, which is especially the case in the projects aimed at realizing flood safety and water retention. This could be due to the obligation on the part of the public actors to take measures. For instance with regard to flood safety, measures have to be taken to guarantee that dikes or dams offer the legal minimum flood safety level. Solid agreements are deemed necessary to avoid free-riding and noncompliance, which confirmed our expectation of the need for legal certainty functions as an important hampering mechanism for flexible arrangements. 
Table 8. Flexibility of the content from a legal perspective.

\begin{tabular}{ll}
\hline Noordwaard & $\begin{array}{l}\text { Rules on compensation are binding and enforceable and hence not flexible; rules on maintenance are flexible because } \\
\text { monitoring is used to determine need for maintenance. }\end{array}$ \\
Rules on compensation are binding and enforceable and hence not flexible; rules on maintenance are flexible because \\
monitoring is used to determine need for maintenance. \\
Unknown, as long as the content of the agreement has to be negotiated. \\
Midden Delfland & $\begin{array}{l}\text { Once the water authorities take decisions, they are final and not meant to be changed. } \\
\text { Essche Stroom } \\
\text { Loosdrecht }\end{array}$ \\
change is not foreseen in the decision. & The parties have not (yet) concluded binding agreements; the green deal is flexible and marks only a beginning. \\
Water farming & The content of the agreement is binding; it is possible to change the rules by mutual agreement (occurred). \\
Storing water & The content of the agreement is binding. \\
Waalblok & The measure is based on public set of rules that deal with the water safety and spatial issues, which are binding and \\
Noordwijk & enforceable.
\end{tabular}

Table 9. Flexibility of the agreements.

\begin{tabular}{|c|c|}
\hline Noordwaard & $\begin{array}{l}\text { The decision to relocate the levees is not to be changed; the agreements on compensation are binding and not meant to be } \\
\text { changed, rules on maintenance can be changed. }\end{array}$ \\
\hline Overdiep & $\begin{array}{l}\text { The decision to relocate the levees is not to be changed; the agreements on compensation are binding and not meant to be } \\
\text { changed. The responsibilities for maintenance have been divided by law and agreement (dyke is public, terps are private } \\
\text { responsibility). }\end{array}$ \\
\hline Midden Delfland & Unknown as long as the agreement has to be negotiated. \\
\hline Essche Stroom & Once the water authorities take decisions, they are final and not meant to be changed. \\
\hline Loosdrecht & Since the decision has become final, change is not foreseen. \\
\hline Water farming & The parties have not (yet) committed themselves to a binding agreement, so they can still change the type of arrangement. \\
\hline $\begin{array}{l}\text { Storing water } \\
\text { at the source }\end{array}$ & If a termination date is included, parties can end their agreement, otherwise it requires mutual agreement to create new ones. \\
\hline Waalblok & $\begin{array}{l}\text { It is possible to create new agreements with different parties or to change the current agreement through mutual agreement } \\
\text { between the parties involved. }\end{array}$ \\
\hline Noordwijk & Type of agreements are very hard to change (legally bounded). \\
\hline
\end{tabular}

Table 10. Summary of findings: assessing the flexibility of arrangements used (from - to +).

\begin{tabular}{|c|c|c|c|c|c|c|}
\hline & \multicolumn{3}{|c|}{ Interaction perspective } & \multicolumn{2}{|c|}{ Legal perspective } & \multirow[t]{2}{*}{ Overall flexibility } \\
\hline & $\begin{array}{l}\text { Flexibility } \\
\text { process }\end{array}$ & $\begin{array}{l}\text { Flexibility } \\
\text { content }\end{array}$ & Flexibility structure & $\begin{array}{l}\text { Flexibility } \\
\text { content }\end{array}$ & Flexibility agreement & \\
\hline Noordwaard & $+/-$ & + & + & - & - & $+/-$ \\
\hline Overdiep & + & + & + & - & - & $+/-$ \\
\hline Midden Delfland & - & - & $+/-$ & - & - & - \\
\hline $\begin{array}{l}\text { Essche } \\
\text { stroom }\end{array}$ & + & $?$ & + & - & - & $+/-$ \\
\hline Loosdrecht & - & - & + & - & - & - \\
\hline Water Farming & + & + & + & + & + & + \\
\hline $\begin{array}{l}\text { Storing water at } \\
\text { the Source }\end{array}$ & - & $+/-$ & - & $+/-$ & $+/-$ & $+/-$ \\
\hline Waalblok & - & + & + & - & $+/-$ & $+/-$ \\
\hline Noordwijk & - & - & - & - & - & - \\
\hline Overall & $+/-$ & $+/-$ & + & - & $+/-$ & \\
\hline
\end{tabular}


However, other actors also try to fix agreements to obtain legal certainty and ensure their rights in the long term, with regard to compensation, for example. The ultimate arrangements have to consolidate the consensus or package deal realized and the various interests that are incorporated. Actors do need a certain guarantee that their interests are also safeguarded in the long run. The focus on goal realization and safeguarding this result is also related to low levels of trust among participants, which is clearly the case in Waalblok, for example. To deal with conflicting interests and a lack of trust actors opt for solid, difficult-to-adjust arrangements.

An unclear distribution of costs and future benefits also forms a strong barrier for flexible arrangements. Actors hackle uncertainties in policy processes. The fact that future benefits of climate adaptation measures are sometimes unclear, makes actors more willing to stick to solid arrangements. There is a discrepancy between the long-term benefits and the short-term costs. To balance those, actors opt for solid agreements. These solid agreements are used by actors to fulfil the wishes of their home organizations. In short, we call this hampering mechanism the institutional urge for fixation.

A cultural factor also appears to strongly influence the outcome in our cases. Among water authorities, in particular the National Agency of Water Works, there is a strong focus on classic project management. It seems a dominant practice to aim at implementation of a measure within a predefined scope, budget, and time horizon. The involved actors stick to standard operating procedures and are often ignorant of other possibilities. The involved authorities are often not acquainted with innovative policy instruments and multiactor partnerships. They easily stick to traditional routines and "normal" instruments, which are often less flexible. The frequent use of formal agreements is also a clear example of this tendency. Following habits, including project management habits, thus constitutes a serious hampering mechanism to the realization of adaptive implementation arrangements.

This brings us to a more general conclusion. The reason why it is difficult to develop flexible arrangements has especially to do with the institutional context in which it has to happen. This context favors certain ways of doing above others, and thus pushes actors to opt for more rigid arrangements. The rule of law and principles of good governance (legality, judicial protection, equality) are part of this context and set boundaries on the application of flexible arrangements. This institutional context is characterized by path-dependency: the use of more solid arrangements in the past, makes it difficult to implement novel arrangements that are more flexible. This issue of institutional rigidity is frequently addressed in the literature on adaptive governance, and our analysis underpins the necessity to think about legal reform and institutional redesign (Méndez et al. 2012, Garmestani and Benson 2013).

At the same time there are also some drivers for flexibility observable. The "Water farming" case especially offers a good example of a flexible arrangement. A simple explanation for this is the pilot status of this project in which all actors are committed to experiment and learn in an informal context. By experimenting and learning they can gradually improve the effectiveness of this joint approach. It would be interesting to see whether this flexibility is grasped in the future of the adaptation measure project. Sometimes budgetary cuts and substantial complexity can stimulate flexibility. A lack of finances precludes the possibility to implement a certain measure in one time, and brings actors to take smaller steps and adapt to the process depending on finances available. The Essche Stroom case shows such a programmatic approach with flexibility to adjust planning and priorities and room for step-wise implementation.

Our analysis reveals that, although there is much attention for adaptive governance, both in literature and in practice, the arrangements used to implement adaptation measures are still dominated by a focus on robust measures, accompanied by solid and rather inflexible arrangements. Whereas the cases are at first quite flexible from an interaction perspective, once a measure is agreed upon, much is invested in consolidating the outcomes of processes of collaboration and negotiation and there are few, if any, provisions for adjusting these outcomes over time. This is caused by the administrative and legal culture that predominates and the habits of the actors involved. It seems that a long path of institutional and cultural modification is necessary before public authorities are able to routinely apply the logic of adaptiveness in implementing adaptation policies. Experiments in pilot projects that focus on the involvement of locals to a great extent, could be a means to steer actors toward a more adaptive approach.

${ }^{[1]}$ Robustness is a characteristic of a system or policy and refers to levels to which the "service" of the system and the outcome of the policy is vulnerable for variations or changing circumstances. In this sense it is the reverse of vulnerable (Mens et al. 2011).

Responses to this article can be read online at: http://www.ecologyandsociety.org/issues/responses. $\mathrm{php} / 7704$

\section{Acknowledgments:}

This research was part of a research project within the Knowledge for Climate project: HSDR 3.5 Adaptive Implementation Arrangements. We want to thank Knowledge for Climate and the Dutch Province of Noord-Brabant for funding this project. We want to thank our partners in this project for their fruitful cooperation. We also want to thank the anonymous reviewers for their excellent comments on earlier versions of this article.

\section{LITERATURE CITED}

Adger, W. N., S. Agrawala, M. M. Q. Mirza, C. Conde, K. O’Brien, J. Pulhin, R. Pulwarty, B. Smit, and K. Takahashi. 2007. Assessment of adaptation practices, options, constraints and capacity. Pages 717-743 in M.L. Parry, O.F. Canziani, J.P. Palutikof, P.J. van der Linden and C.E. Hanson, editors. Climate change 2007: impacts, adaptation and vulnerability. Contribution of Working Group II to the Fourth Assessment Report of the Intergovernmental Panel on Climate Change. Cambridge University Press, Cambridge, UK. 
Adger, W. N., N. W. Arnell, and E. L. Tompkins. 2005. Successful adaptation to climate change across scales. Global Environmental Change 15:77-86. http://dx.doi.org/10.1016/j.gloenvcha.2004.12.005

Allen, C. R., and L. H. Gunderson. 2011. Pathology and failure in the design and implementation of adaptive management. Journal of Environmental Management 92(5):1379-1384. http:// dx.doi.org/10.1016/j.jenvman.2010.10.063

Amundsun, H., F. Berglund, and H. Westskog. 2010. Overcoming barriers to climate change adaptation - a question of multilevel governance? Environment and Planning C: Government and Policy 28:276-289. http://dx.doi.org/10.1068/c0941

Armitage, D., M. Marschke, and R. Plummer. 2008. Adaptive comanagement and the paradox of learning. Global Environmental Change 18:86-98. http://dx.doi.org/10.1016/j.gloenvcha.2007.07.002

Arnold, C., and L. H. Gunderson. 2013. Adaptive law and resilience. Environmental Law Reporter (43):10426-10442.

Benson, M. H., and A. S. Garmestani. 2011. Embracing panarchy, building resilience and integrating adaptive management through a rebirth of the National Environmental Policy Act. Journal of Environmental Management 92(5):1420-1427. http://dx.doi. org/10.1016/j.jenvman.2010.10.011

Berkes, F., and D. Jolly. 2002. Adapting to climate change: socialecologic resilience in a Canadian Western Artic Community. Conservation Ecology 5(2): 18. [online] URL: http://www. consecol.org/vol5/iss2/art18/

Biesbroek, G. R. 2014. Challenging barriers in the governance of climate change adaptation. Dissertation, Wageningen University, Wageningen, The Netherlands.

Biesbroek, G. R., R. J. Swart, T. R. Carter, C. Cowan, T. Henrichs, H. Mela, M. D. Morecroft, and D. Rey. 2010. Europe adapts to climate change: comparing national adaptation strategies. Global Environmental Change 20(3):440-450. http://dx.doi.org/10.1016/ j.gloenvcha.2010.03.005

Biesbroek, R., J. Klostermann, C. Termeer, and P. Kabat. 2011. Barriers to climate change adaptation in the Netherlands. Climate Law 2:181-199. http://dx.doi.org/10.3233/CL-2011-033

Blumer, H. 1969. Symbolic interactionism. Perspectives and methods. Prentice Hall, Englewood Cliffs, New Jersey, USA.

Breman, B., M. Pleijte, S. Ouboter, and A. Buijs. 2008. Participatie in waterbeheer. Een vak apart. Wageningen University, Wageningen, The Netherlands.

Breman B. C., R. J. Fontein, M. de Groot. 2011. Meerwaarde(n) mogelijk maken; een onderzoek naar het belang van waarden in gebiedsontwikkeling. Alterra-rapport 2261. Alterra, Wageningen, The Netherlands.

Brunner, R. D., and A. H. Lynch. 2013. Adaptive governance and climate change. American Meteorological Society, Boston, Massachusetts, USA. http://dx.doi.org/10.1007/978-1-935704-01-0

Chaffin, B. C., H. Gosnell, and B. A. Cosens. 2014. A decade of adaptive governance scholarship: synthesis and future directions. Ecology and Society 19(3): 56. http://dx.doi.org/10.5751/ ES-06824-190356
Cook, W. M., D. G. Casagrande, D. Hope, P. M. Groffman, and S. L. Collins. 2004. Learning to roll with the punches: adaptive experimentation in human-dominated systems. Frontiers in Ecology and the Environment 2(9):467-474. http://dx.doi. org/10.1890/1540-9295(2004)002[0467:1trwtp]2.0.co:2

Cosens, B. 2010. Transboundary river governance in the face of uncertainty: resilience theory and the Columbia River Treaty. Journal of Land, Resources, and Environmental Law 30 (2):229-265.

Craig, R. K. 2010. 'Stationarity is dead' - long live transformation: five principles for climate change adaptation law. Harvard Environmental Law Review 34(1):9-75.

Craig, R. K., and J. B. Ruhl. 2014 Designing administrative law for adaptive management. Vanderbilt Law Review 67(1):1-87.

Cundill, G., and R. Rodela. 2012. A review of assertions about the processes and outcomes of social learning in natural resource management. Journal of Environmental Management 113:7-14. http://dx.doi.org/10.1016/j.jenvman.2012.08.021

Ebbesson, J. 2010. The rule of law in governance of complex socioecological changes. Global Environmental Change 20(3):414-422. http://dx.doi.org/10.1016/j.gloenvcha.2009.10.009

Ellen, G. J., and B. Ottow. 2012. Maatschappelijke aspecten van flexibel peilbeheer. Deltares rapport 1202707-003-BGS-0015, Deltares, Utrecht, The Netherlands.

Eshuis, J., and A. van Buuren. 2014. Innovations in water governance: the importance of time. International Review of Administrative Sciences 80(2):401-420. http://dx.doi. org/10.1177/0020852313514518

Fankhauser, S., J. B. Smith, and R. S. J. Tol. 1999. Weathering climate change: some simple rules to guide adaptation decisions. Ecological Economics 30(1):67-78. http://dx.doi.org/10.1016/ s0921-8009(98)00117-7

Flyvbjerg, B. 2006. Five misunderstandings about case-study research. Qualitative Inquiry 12(2):219-245. http://dx.doi. org/10.1177/1077800405284363

Folke, C., T. Hahn, P. Olsson, and J. Norberg. 2005. Adaptive governance of social-ecological systems. Annual Review of Environment and Resources 30:441-473. http://dx.doi.org/10.1146/ annurev.energy.30.050504.144511

Füssel, H.-M. 2007. Adaptation planning for climate change: concepts, assessment approaches, and key lessons. Sustainability Science 2(2):265-275. http://dx.doi.org/10.1007/s11625-007-0032$\mathrm{y}$

Gambetta, D. 1988. Trust: making and breaking cooperative relations. Basil Blackwell, New York, New York, USA.

Garmestani, A. S., C. R. Allen, and H. Cabezas. 2008. Panarchy, adaptive management and governance: policy options for building resilience. Nebraska Law Review 87:1036.

Garmestani, A. S., and M. H. Benson. 2013. A framework for resilience-based governance of social-ecological systems. Ecology and Society 18(1): 9. http://dx.doi.org/10.5751/ES-05180-180109 
Giddens, A. 2009. The politics of climate change. Cambridge University Press, Cambridge, UK.

Gilissen, H. K., M. Kok, J. Edelenbos, H. F. M. W. van Rijswick, P. Hillegers, G. R. Teisman. 2010. Governance analysis case Noordwijk: 'weak links' along the coast. Utrecht University, Utrecht, The Netherlands.

Green, O. O., A. S. Garmestani, H. F. M. W. van Rijswick, and A. M. Keessen. 2013. EU water governance: striking the right balance between regulatory flexibility and enforcement. Ecology and Society 18(2): 10. http://dx.doi.org/10.5751/es-05357-180210

Gunningham, N. 2009. Environment law, regulation and governance: shifting architectures. Journal of Environmental Law 21(2):179-212. http://dx.doi.org/10.1093/jel/eqp011

Gupta, J., C. Termeer, J. Klostermann, S. Meijerink, M. van den Brink, P. Jong, S. Nooteboom, and E. Bergsma. 2010. The adaptive capacity wheel: a method to assess the inherent characteristics of institutions to enable the adaptive capacity of society. Environmental Science \& Policy 13(6):459-471. http://dx. doi.org/10.1016/j.envsci.2010.05.006

Hallegatte, S. 2009. Strategies to adapt to an uncertain climate change. Global Environmental Change 19(2):240-247. http://dx. doi.org/10.1016/j.gloenvcha.2008.12.003

Hammersly, M. 2010. Can we re-use qualitative data via secondary analysis? Notes on some terminological and substantive issues. Sociological Research Online 15(1)5. http://dx. doi.org/10.5153/sro.2076

Howarth, W. 2009. Aspirations and realities under the water framework directive: proceduralisation, participation and practicalities. Journal of Environmental Law 21(3):391-417. http:// dx.doi.org/10.1093/jel/eqp019

Huitema, D., E. Mostert, W. Egas, S. Moellenkamp, C. PahlWostl, and R. Yalcin. 2009. Adaptive water governance: assessing the institutional prescriptions of adaptive (co-) management from a governance perspective and defining a research agenda. Ecology and society 14(1): 26. [online] URL: http://www.ecologyandsociety. org/vol14/iss1/art26/

Huntjens, P. 2011. Water management and water governance in a changing climate: experiences and insights on climate change adaptation in Europe, Africa, Asia and Australia. Eburon Academic, Delft, The Netherlands.

Huntjens, P., L. Lebel, C. Pahl-Wostl, J. Camkin, R. Schulze, and N. Kranz. 2012. Institutional design propositions for the governance of adaptation to climate change in the water sector. Global Environmental Change 22(1):67-81. http://dx.doi. org/10.1016/j.gloenvcha.2011.09.015

Klijn, E. H. 1996. Regels en sturing in netwerken. De invloed van netwerkregels op de hertructurering van naoorloogse wijken. Eburon, Delft, The Netherlands.

Lebel, L., T. Grothmann, and B. Siebenhüner. 2010. The role of social learning in adaptiveness: insights from water management. International Environmental Agreements: Politics, Law and Economics 10(4):333-353. http://dx.doi.org/10.1007/s10784-010-9142-6
Lee, K. N. 1999. Appraising adaptive management. Conservation Ecology 3(2): 3. [online] URL: http://www.ecologyandsociety.org/ vol3/iss $2 / \operatorname{art} 3 /$

March, J. G., and J. P. Olsen. 1989. Rediscovering institutions: the organizational basis of politics. Free Press, New York, New York, USA.

Mees, H. L. P., J. Dijk, D. van Soest, P. P. J. Driessen, M. H. F. M. W. van Rijswick, and H. Runhaar 2014. A method for the deliberate and deliberative selection of policy instrument mixes for climate change adaptation. Ecology and Society 19(2): 58. http://dx.doi.org/10.5751/es-06639-190258

Méndez, P. F., N. Isendahl, J. M. Amezaga, and L. Santamaría. 2012. Facilitating transitional processes in rigid institutional regimes for water management and wetland conservation: experience from the Guadalquivir Estuary. Ecology and Society 17(1): 26. http://dx.doi.org/10.5751/es-04494-170126

Mens, M. J. P., F. Klijn, K. De Bruijn, and E. van Beek. 2011. The meaning of system robustness for flood risk management. Environmental Science and Policy 14:1121-1131. http://dx.doi. org/10.1016/j.envsci.2011.08.003

Moser, S. C., and J. A. Ekstrom. 2010. A framework to diagnose barriers to climate change adaptation. Proceedings of the National Academy of Sciences 107(51):22026-22031. http://dx.doi. org/10.1073/pnas. 1007887107

Naess, L. O., G. Bang, S. Eriksen, and J. Vevatne. 2005. Institutional adaptation to climate change: flood responses at the municipal level in Norway. Global Environmental Change 15 (2):125-138. http://dx.doi.org/10.1016/j.gloenvcha.2004.10.003

Newig, J., C. Pahl-Wostl, and K. Sigel. 2005. The role of public participation in managing uncertainty in the implementation of the Water Framework Directive. European Environment 15:333-343. http://dx.doi.org/10.1002/eet.398

Olsson, P., L. H. Gunderson, S. R. Carpenter, P. Ryan, L. Lebel, C. Folke, and C. S. Holling. 2006. Shooting the rapids: navigating transitions to adaptive governance of social-ecological systems. Ecology and Society 11(1): 18. [online] URL: http://www. ecologyandsociety.org/vol11/iss1/art18/

Pahl-Wostl, C. 2007. Transitions towards adaptive management of water facing climate and global change. Water Resources Management 21(1):49-62. http://dx.doi.org/10.1007/s11269-006-9040-4

Pahl-Wostl, C. 2009. A conceptual framework for analysing adaptive capacity and multi-level learning processes in resource governance regimes. Global Environmental Change 19(3):354-365. http://dx.doi.org/10.1016/j.gloenvcha.2009.06.001

Pierson, P. 2004. Politics in time: history, institutions and social analysis. Princeton University Press, Princeton, New Jersey, USA.

Plummer, R., D. R. Armitage, and R. C. De Loë. 2013. Adaptive comanagement and its relationship to environmental governance. Ecology and Society 18(1): 21. http://dx.doi.org/10.5751/ es-05383-180121 
Ring, P. A., and A. Van de Ven. 1994. Development processes of cooperative interorganizational relationships. Academy of Management Review 19:90-118.

Ruhl, J. B. 2011. General design principles for resilience and adaptive capacity in legal systems - with applications to climate change adaptation. North Carolina Law Review 89(5):1374-1401.

Scharpf, F. W. 1997. Games real actors play. Actor-centred institutionalism in policy research. Westview, Boulder, Colorado, USA.

Seal, C. 2011. Secondary analysis of qualitative data. Pages 347-364 in D. Silverman, editor. Qualitative research. Third edition. Sage, Thousand Oaks, California, USA.

Sutton, S. G., and R. C. Tobin. 2011. Constraints on community engagement with Great Barrier Reef climate change reduction and mitigation. Global Environmental Change 21(3):894-905. http://dx.doi.org/10.1016/j.gloenvcha.2011.05.006

Szabo, V., and V. R. Strang. 1997. Secondary analysis of qualitative data. Advances in Nursing Science 20(2):66-74. http:// dx.doi.org/10.1097/00012272-199712000-00008

Termeer, C. J. A. M., A. R. P. J. Dewulf, H. F. M. W. van Rijswick, A. van Buuren, D. Huitema, S. Meijerink, T. Rayner, and M. Wiering. 2011. The regional governance of climate adaptation: a framework for developing legitimate, effective, and resilient governance arrangements. Climate Law 2(2):159-179.

Van Bakel, J., B. Bardoel, D. Boland, N. Entzinger, I. Menger, and C. en van Rens. 2013. Pilots water vasthouden aan de bron, Eindrapport. Provincie Noord-Brabant, 's Hertogenbosch, The Netherlands.

Van Buuren, A., P. Driessen, G. R. Teisman, and M. van Rijswick. 2014. Towards legitimate governance strategies for climate adaptation in the Netherlands: combining insights from a legal, planning, and network perspective. Regional Environmental Change 14(3):1021-1033. http://dx.doi.org/10.1007/s10113-013-0448-0

Van Buuren, A., E. H. Klijn, and J. Edelenbos. 2012. Democratic legitimacy of new forms of water management in the Netherlands. International Journal of Water Resources Development 28 (4):629-645. http://dx.doi.org/10.1080/07900627.2011.627756

van Rijswick, H. F. M. W., and H. J. M. Havekes. 2012. European and Dutch water law. Europa Law Publishing, Groningen, The Netherlands.

van Tatenhove, J. 2013. How to turn the tide: developing legitimate marine governance arrangements at the level of the regional seas. Ocean \& Coastal Management 71:296-304. http://dx.doi. org/10.1016/j.ocecoaman.2012.11.004

Visser, M. 2012. Aquifer storage and recovery in a fossil creek bed. Managing droughts in a brackish environment. Thesis, University Utrecht, Utrecht, The Netherlands.

Wade, H. W. R., and C. F. Forsyth. 2000. Administrative law. Eighth edition. Oxford University Press, Oxford, UK.

Winnubst, M. 2011. Turbulent waters. Cross-scale conflict and collaboration in river lanscape planning. Radboud Universiteit, Nijmegen, The Netherlands.
Zerubavel, E. 2003. Time maps. Collective memory and the social shape of the past. University of Chicago Press, Chicago, Illinois, USA. http://dx.doi.org/10.7208/chicago/9780226924908.001.0001 